\title{
The Effects of Trade Policy on Trade among the EU and BRICS Countries
}

\author{
Bohdan VAHALÍK - Lenka FOJTÍKOVÁ*
}

\begin{abstract}
The aim of this paper is to estimate whether the liberalization process benefited a mutual trade between the EU and BRICS Members over the last two decades, and whether protectionism, which is currently on the rise, still represents a significant toll to trade. Our results proved that the multilateral trade liberalization process, represented by the WTO, is no longer benefiting trade among observed economies. It clearly confirms the long-standing stalemate in the WTO. We have also found that the observed FTA between the EU and South Africa created trade strongly, but unevenly. Finally, we found that the level of tariffs no longer represents a significant barrier to trade among observed countries.
\end{abstract}

Keywords: BRICS, European Union, international trade, gravity model, trade policy

JEL Classification: C33, F11, F13, F14, F41

DOI: https://doi.org/10.31577/ekoncas.2020.09.03

\section{Introduction}

Political and structural changes in Brazil, Russia, India, China and South Africa (BRICS) during the late 1980s and 1990s and their following development have had a significant effect on global trade.

For this reason, the European Union (EU) revised its position towards BRICS members in order to improve trade relations and fulfill its aim of progressive abolition of trade restrictions, lowering the customs duties and other trade barriers in the long term.

\footnotetext{
* Bohdan VAHALÍK - Lenka FOJTÍKOVÁ, VSB-Technical University of Ostrava, Faculty of Economics, Department of International Economic Relations, Sokolská třída 33, 70100 Ostrava, Czech Republic; e-mail: bohdan-vahalik@gmail.cz; lenka.fojtikova@vsb.cz

The authors declare that they have no conflict of interest.
} 
After the EU enlargement and adoption of the Lisbon Treaty, the European Commission created a new EU Trade and Investment Strategy with the time horizon of 2020, following the Europe 2020 Strategy. In terms of trade policy, the completion of ongoing negotiations on multilateral and bilateral trade agreements and the creation of new ways for cooperation with others has become the main priority within the EU Common Commercial Policy. The European Commission estimated that the mere implementation of existing trade agreements with strategic partners could increase the size of the EU gross domestic product (GDP) by 150 billion EUR (European Commission, 2011). Moreover, the new EU Trade and Investment Strategy emphasized the need to target its trade policy especially at the markets of the United States, China, Russia, Japan, India, and Brazil. The emphasis on relations with BRICS countries is obvious. However, the recent increase of protectionist rhetoric and measures in the global economy, triggered by the US president Donald Trump, coupled with an unsuccessful WTO round and Brexit, may take a toll on the trade negotiations among the EU and other countries. For the above-mentioned reasons, the paper aims to estimate the effect of trade policy measures on trade with goods among the EU and BRICS countries. ${ }^{1}$ We focus on the effects that were supposed to come out from the multilateral and bilateral trade agreements as well as on existing tariff barriers that still remain.

\section{The EU Trade Policy with BRICS Countries}

Since 2010, the EU has been negotiating an Association Agreement with Brazil via the EU-Mercosur trade agreement. ${ }^{2}$ Brazil is the EU's most important trading partner in the Latin America region and the EU is Brazil's second biggest trading partner (after China), accounting for 16\% of its total trade (European Commission, 2020a). Despite that, Brazil keeps quite high tariff and non-tariff barriers. A study made by the University of Manchester in 2008 reports that a full liberalization of trade between the EU and Mercosur would increase the EU's production by $0.1 \%$ and the production of Brazil by $1.5 \%$, excluding other dynamic effects (Hinojosa-Valencia, Hinojosa and DG-Trade, 2008). The most

\footnotetext{
${ }^{1}$ The paper avoids trade in commercial services and deals only with trade in goods. The reason is the lack of information about trade in services and missing opportunity to analyse the effect of tariffs on the trade flows of commercial services. Despite the fact that trade in services has increased its share in global trading, its share in trade between the EU and BRICS countries still remains negligible compared to trade in goods.

${ }^{2}$ The EU-Mercosur Association Agreement has in fact been negotiated since 1999. However, the negotiations were suspended in 2004 and resumed in 2010, focusing on the political and cooperation chapters and the 'normative' part of the trade chapter (rules of origin, etc.).
} 
recent study suggests an increase of the EU's production capacity by $1 \%$ and Brazil's by 2\% (London School of Economics, 2019). The negotiations took 20 years. In 2019, the European Commission reached a political agreement with Mercosur states, but when the agreement will be signed remains unclear.

The EU also wanted to establish deeper economic relations with Russia. Russia is the EU's fifth largest trading partner and the EU is Russia's largest trading partner. Both economies rely heavily on each other as many of the EU countries are dependent on Russia's exports of natural resources (mainly oil and gas), while Russia's economic development is, to a large extent, dependent on export revenues. The Common Economic Space Agreement (CESP) was introduced as early as 2003 and was supposed to remove most trade barriers, create a new common regulation, building a backbone infrastructure and exchange of information. Unfortunately, before the agreement could bring first clear benefits, the political and military conflict on the Russian-Ukraine border and annexation of Crimea stopped all EU efforts for negotiations. Even though Russia entered the WTO in 2012, the mutual trade relations with many, mainly western, economies, rather worsened, which is proven by the increasing number of trade disputes, economic sanctions, etc. We do not assume that the EU-Russia trade negotiations will be re-established any time soon, as the mutual trade relations will remain highly dependent on the political situation.

In the case of India, its share of trade with the EU remained relatively small in the last two decades. Nevertheless, the EU countries are an important market for India (14\% of the total Indian exports). The EU and India were negotiating a comprehensive free trade agreement (FTA) since 2007, covering mainly free access in goods, services, public procurement and investment. ${ }^{3}$ However, the negotiations were suspended in 2013 due to a gap in the level of ambition. It is estimated that the FTA could increase the mutual trade turnover by USD $23-26$ billion (European Commission, 2020b).

The EU and China are the two biggest traders in the world. China is currently the EU's second biggest trading partner, after the United States, and the EU is the biggest trading partner for China. The mutual trade accounted for EUR 560 billion in 2019 (4\% of the EU nominal GDP). Despite that, there are no negotiations of trade agreement between both economies. ${ }^{4}$ The European Commission comments on several reasons for that (European Commission, 2020c):

\footnotetext{
${ }^{3}$ So far, India has introduced some changes in investment rules and has opened the possibility of $100 \%$ foreign ownership in the telecommunication sector. Similarly, the government increased investment limits in the armaments and insurance sectors from $26 \%$ to $49 \%$ (European Commission, 2020b).

${ }^{4}$ Despite this, the European Commission launched negotiations on the Comprehensive Investment Agreement in 2013.
} 
- A lack of transparency,

- China's industrial policies and non-tariff measures that discriminate against foreign companies,

- Strong government intervention in the economy that results in a dominant position of state-owned companies, unequal access to subsidies and cheap financing,

- Poor protection and enforcement of intellectual property rights.

Based on these issues, coupled with recent geopolitical tensions, trade disputes between China and the USA, increasing pressure on Hong Kong, technological thefts and many other things, any negotiations of trade agreement are highly unlikely even in the long term.

South Africa is the only country of BRICS that keeps a valid Free Trade Agreement with the EU. However, the agreement still does not fully cover all areas of trade with goods. ${ }^{5}$ The liberalization process was completed by 2012 . Since the Agreement came into force (2004), the mutual trade between the EU and South Africa has more than doubled, and the volume of foreign investment has even increased fivefold (European Commission, 2020d). The claim that this development was determined by this FTA would be too strong, of course. Therefore, we will estimate the effect of the EU-South Africa FTA in the empirical part.

As the EU FTA with South Africa was already in place, the EU-Mercosur trade agreement is the only promising trade agreement that includes BRICS countries in the near future. The above-mentioned facts suggest that the EU Trade and Investment Strategy was very ambitious, and that the European Commission was not able to fulfill its obligations during the last decade. Rather the opposite, the Brexit is a big warning for the EU that the European integration process is not a matter of course and that a deep and broad reform is needed.

\section{The EU Trade with BRICS and Tariff Barriers}

The importance of BRICS countries for the EU has increased significantly during the last three decades. This claim is not based only on increasing trade with goods, but also on trade with services, investment, cooperation, etc. In this paper, we focus only on trade with goods between the EU members and BRICS countries as only this part of trade gives a clear view on the effects of liberalization and protectionism. ${ }^{6}$

\footnotetext{
${ }^{5}$ The EU-South Africa FTA does not include all aspects of agriculture goods; there are exceptions in the automotive industry on the side of South Africa and textile on the side of the EU.

${ }^{6}$ The estimation of non-tariff measures on services, investment, and intellectual property rights would deserve its own research. For the same reason, the paper avoids non-tariff barriers on goods.
} 
The weight of BRICS countries increased significantly mainly on the EU import side. As seen in Figure 1, the share of EU imports from BRICS countries increased from 5\% in 1995 to almost $14 \%$ in 2018, mainly on behalf of China. ${ }^{7}$ The share of Russia depends significantly on the oil prices (as seen on the decline in 2016), while the share of other BRICS countries did not change much.

Fig u r e 1

The Importance of BRICS in the EU Trade is Increasing; However, Not Equally

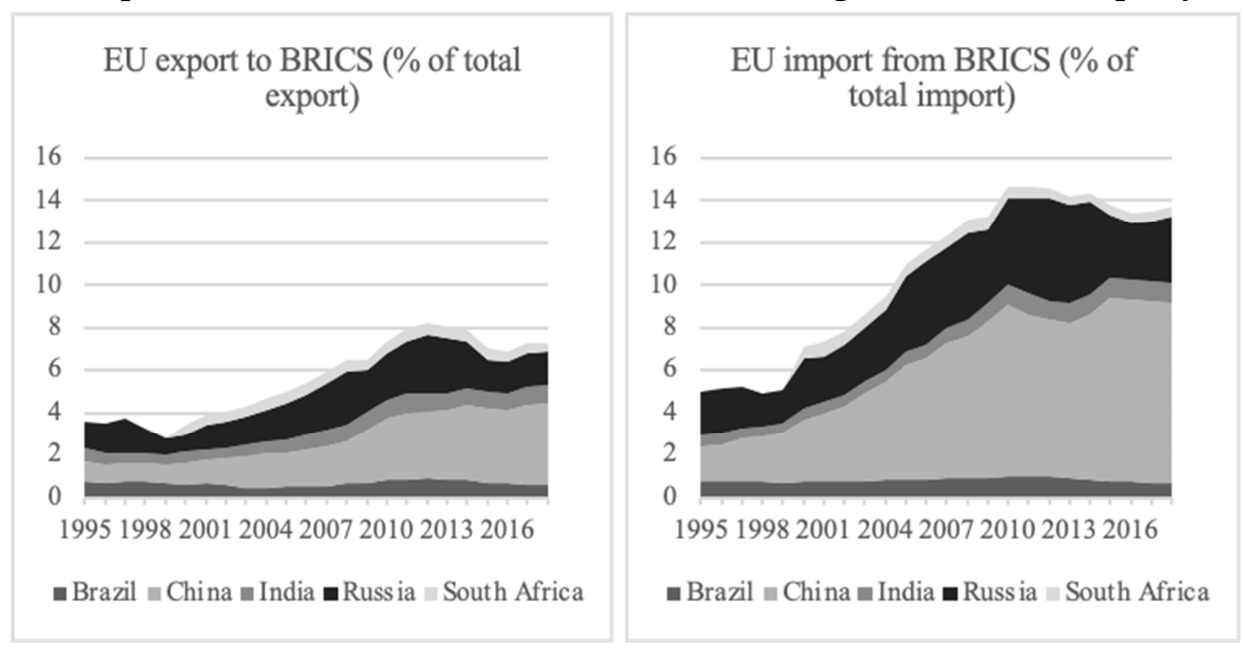

Source: UNCTAD (2020); own elaboration, 2020.

On the other hand, the data show that the share of the EU exports to BRICS has increased only on behalf of China and Russia since 1995, while share of other countries has not changed significantly. Using the same scale, one can also notice a difference between the EU-BRICS share of exports and imports. This suggests quite large EU demand for goods from BRICS countries, while the EU products are struggling to penetrate BRICS markets. To what extent it is caused by higher tariff measures on the BRICS side is the subject of research in the empirical part.

Despite the long-term liberalization efforts, tariff barriers still exist creating additional costs which are eventually paid by the customer. It is evident that the EU imports from BRICS countries face much lower tariff barriers than in the opposite direction. In the observed period, the highest EU tariff rates were applied on Brazil exports, while the lowest tariff rates were applied against imports from Russia and South Africa. Apart from India, the EU has substantially reduced the

\footnotetext{
${ }^{7}$ In the time of the preparations of this paper, the last available data for exports and imports were for the year 2018. For this reason, we keep the United Kingdom as an EU member in our database, even though formally it is already a non-EU member country in 2020.
} 
tariff rates to all BRICS countries since 1995 (see Figure 2). Above all, the gradual reduction of tariffs against the South African exports can be seen since 1999, as it follows the implementation of the EU-South Africa trade agreement.

Fig u re 2

The EU Weighted Average Effective Applied Tariff Rate on Imports from BRICS in the Period 1995 - $2016(\%)$

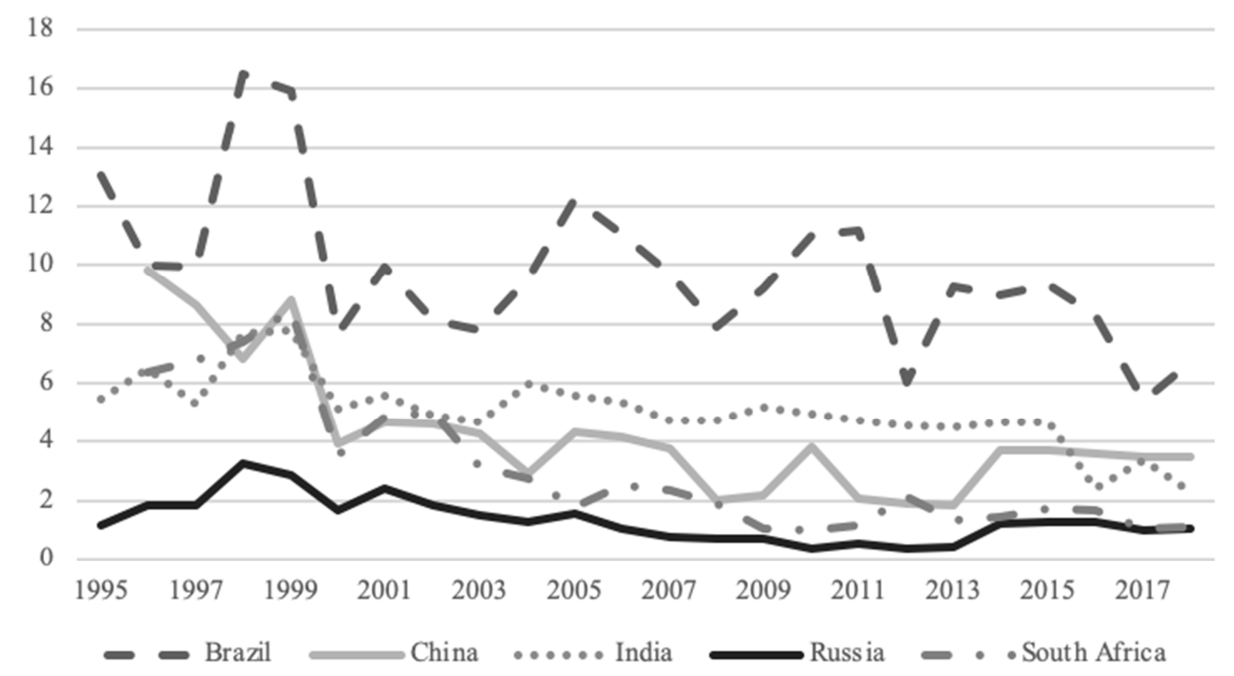

Source: World Bank (2020); own elaboration, 2020.

Figure 3

The BRICS Weighted Average Effective Applied Tariff Rate on Imports from the EU in the Period 1995 - $2016(\%)$

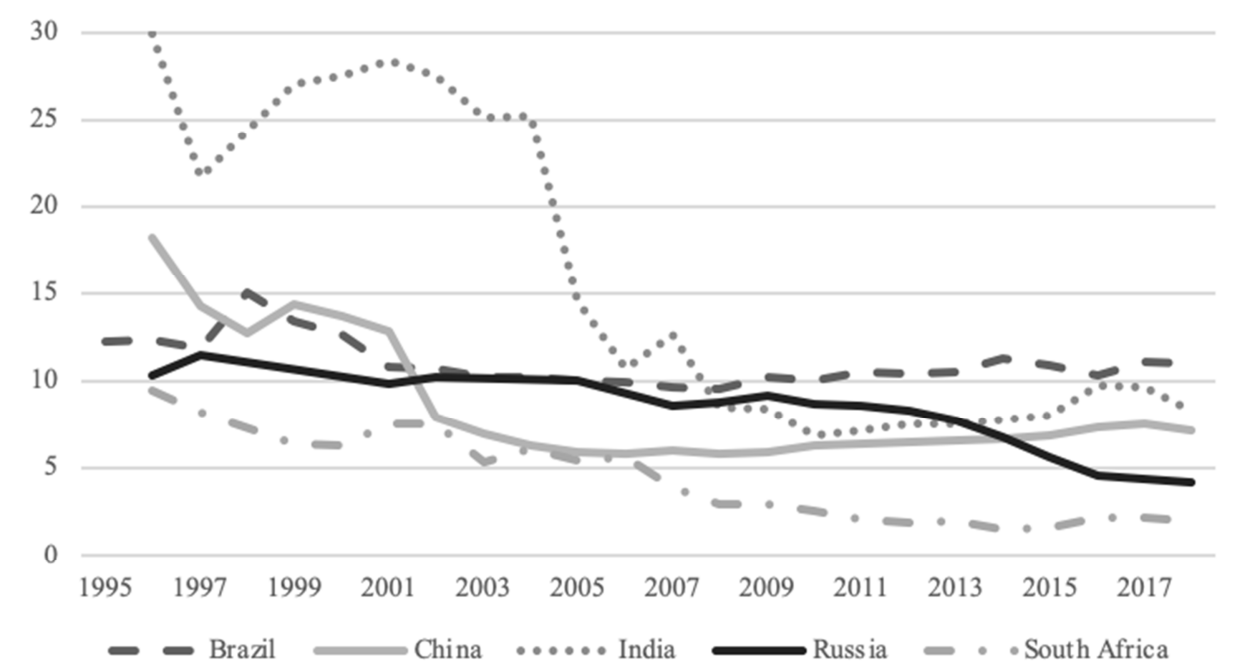

Source: World Bank (2020); own elaboration, 2020. 
The effective applied tariff rates imposed on BRICS imports from the EU countries remain very high (see Figure 3). Brazil and India still keep the highest tariffs of around $10 \%$ on average on the EU imports. ${ }^{8}$ China decreased tariffs by half during 1990s as part of the general effort for WTO membership, however since then, the average applied tariff rate slightly increased. Russia gradually decreased the applied tariff rates on the EU goods on average, mainly in last several years. South Africa applies the lowest level of tariffs in line with the FTA signed in 2000.

\section{Literature Review}

This paper estimates the effect of liberalization and protectionism on international trade. Despite very diverse results in the gravity literature, we will test the hypothesis of the positive effect of trade liberalization and negative effect of tariffs on trade. For example, Rose (2005) produced positive weak effects of the WTO membership (as well as of IMF and OECD membership) after accounting for the diverse trade effects produced by individual preferential trade agreements (PTA). One might imagine that the WTO would have the highest effect, since it is the institution most dedicated to trade liberalization. But Rose (2005) found that the effects of both the IMF and the WTO were rather negligible, sometimes even negative. Only when employing the fixed effects estimator, he found that the process of joining the WTO was associated with a trade-creating effect, though simply belonging to it was not. On the other hand, the OECD membership had a robustly positive effect on trade, which Rose (2005) called as interesting mystery. When Subramanian and Wei (2007) emphasized general equilibrium trade effects by controlling for multilateral resistance, they found strong WTO trade effects benefiting only industrialized countries. They claim that it is caused by a higher participation of industrialized countries in trade negotiations, higher share of reciprocal agreements, and higher effort for trade liberalization. Eicher and Henn (2011) confirmed those results when finding that WTO membership boosted trade prior to PTA formation and increased trade among proximate developing countries. However, they also found that countries with greater incentives to bargain for tariff reductions before the WTO accession experienced positive and significant subsequent WTO trade effects. Garred (2016) found that China's export restrictions increasingly resembled the inverse of its pre-WTO import tariff schedule. We saw in the previous chapter that even China's import tariffs increased slightly in the last years.

\footnotetext{
${ }^{8}$ High Brazilian tariffs are one of the many reasons why the EU-Mercosur FTA could be very beneficial for the EU producers.
} 
Another important question that has been observed in literature is whether free trade agreements increased members' international trade. After forty years of gravity modeling, there were no clear and convincing empirical results that would confirm this claim. Baier and Bergstran (2007) found convincing evidence using panel data, that free trade agreements did support international trade. ${ }^{9}$ Eicher and Henn (2011) found that PTAs created trade strongly, but unevenly across individual agreements. For example, their results show that a strong tariff-reducing EU policy is trade created for its members. They also found that the WTO membership increased trade effects just before PTA accession, whose positive effects were stronger later. These are quite convincing and promising findings as PTAs usually cover a wider range of trade relations and cut deeper into the tariffs schedules that are offered by multilateral treaties. Gill-Pareja, Llorca-Vivero and Martinez-Serrano (2017) pointed out unevenly distributed effects of reciprocal and non-reciprocal trade agreements. They suggest that developing countries should abandon their reliance on one-way trade preferences in favor of reciprocal agreements as they found that reciprocal agreements had a larger positive effect on developing countries' exports.

On the other hand, we will also observe the effect of existing tariffs on bilateral trade flows. Import tariffs have fallen steeply worldwide over the last several decades (Rouzet and Miroudot, 2013). But trade policy keeps protecting its markets by tariffs. Moreover, there is a lot of evidence that governments transmit their policy measures to other trade policy instruments (mainly non-tariff barriers). Does it mean that trade barriers such as tariffs still matter? For example, Genc and Law (2014) created a study of barriers to trade in New Zealand, suggesting that they had a significantly negative effect on New Zealand's exports. ${ }^{10}$ Rouzet and Miroudot (2013) were estimating the impact of tariffs on exports of goods from OECD countries and key emerging economies. They conclude that tariffs still matter and with increasing global fragmentation of production, even small nominal ad valorem tariffs can translate into important costs that will be eventually paid by consumers. Finally, Furceri et al. (2019) observed the macroeconomic consequences of tariffs on 151 countries over $1964-2014$. They found that tariff increases led to, in the medium term, economically and statistically significant declines in domestic output and productivity, higher unemployment and inequality, real exchange rate appreciation, but only to small effects on the trade balance improvement. With improving mathematical models, it seems that the benefits of trade liberalization and costs of protectionism grow in importance.

\footnotetext{
${ }^{9}$ Their estimates ranged from $0.61-0.76$, five to six times higher than the estimates gained using OLS.

${ }^{10}$ The elasticity coefficient of tariffs was -0.2 .
} 


\section{Methodology and Data}

\subsection{Data Specification}

Two gravity models will be estimated in several modifications in the following sub-chapters. Each model explains the bilateral trade flows between the EU Members and BRICS countries, creating a panel of 140 country-pairs (28 EU Member countries and 5 countries of BRICS) ${ }^{11}$ during the period $1995-2018$. The first model covers the BRICS imports from the EU countries while the second one covers the EU Members' imports from BRICS. For comparison purposes, there will always be estimated the same specification for both trade flows to see the differences in the effects and patterns of trade in each direction.

There are many studies of the gravity model that use different variables representing bilateral trade flows. The microeconomic gravity equation describes the modified expenditure function, where the expenditures of one country are used for the purchases of goods that are produced in other countries. It is one of the reasons why we use nominal values of trade flows. ${ }^{12}$ Baldwin and Taglioni (2006) proposed a four-averaging method of trade flows. However, we assume that using a weighted average of bilateral trade flows among two partners causes biased results as trade flows are not usually balanced, especially in the case of North-South trade. Therefore, we follow the methodology of Shepherd (2013) who claims that a gravity model applies to unidirectional export/import flows, hence, each line of the gravity equation should represent trade in only one way. Fukao, Okubo and Stern (2003), Martínez-Zarzoso, Suárez-Burguet (2005) or Lampe (2008) prove the validity of this methodology on empirical evidence. They confirm that the direction of trade may contain an important piece of information, which would be excluded by averaging. A wrong averaging of trade flows leads to the misspecification of the estimates. Finally, as we estimate the effect of tariffs on trade flows, it is necessary to analyze import flows, which are measured in the Cost of Insurance and Freight (CIF) prices, including tariff costs as well.

Table 1 offers a summary of all variables used in the paper and their expected effect on bilateral imports according to the economic theory. The most commonly used time-variant variable in the gravity equation, which creates the core of the model, is a nominal gross domestic product reflecting the economic size of the country, both in terms of production capacity (supply side), and market size (demand side). Both variables are observed in nominal terms in millions USD.

\footnotetext{
${ }^{11}$ We keep the United Kingdom as an EU Member as our observed period contains the period when the United Kingdom was still an EU member.

${ }^{12}$ For the same purpose, we estimate the effect of the nominal exchange rate.
} 
According to the theory of gravity model, both variables should have a positive effect on the bilateral trade flows.

Distance was the part of the gravity model already in Tinbergen's (1962) gravity model and represents the basic barrier to trade. Many studies proved that it was important to control for distance (see Brun et al., 2002; Melitz, 2007; Disdier and Head, 2008; or Behar and Venables, 2011) because it approximates transport costs as well as the time elapsed during the shipment, synchronization costs, communication costs, or transaction costs (Head, 2003).

Table 1

Final List of Variables Used in the Estimated Models

\begin{tabular}{|l|l|l|l|c|l|}
\hline Variables & Units & $\begin{array}{c}\text { Variable } \\
\text { name }\end{array}$ & $\begin{array}{c}\text { Type of } \\
\text { variable }\end{array}$ & $\begin{array}{c}\text { Expected } \\
\text { effect }\end{array}$ & Source \\
\hline Import & mil. USD & $I M_{i j}$ & quantitative & & UNCTAD \\
Exporter's nominal GDP (supply side) & mil. USD & $Y_{i}$ & quantitative & + & UNCTAD \\
Importer's nominal GDP (demand side) & mil. USD & $Y_{j}$ & quantitative & + & UNCTAD \\
Distance & $\mathrm{km}$ & dist $_{i j}$ & quantitative & - & CEPII \\
CMEA membership & 0,1 & cmea $_{i j}$ & dummy & + & WTO \\
WTO membership & 0,1 & $w t o_{i j}$ & dummy & + & WTO \\
Preferential agreement & 0,1 & $f t a_{i j}$ & dummy & + & EC \\
Tariff barrier & $\%$ & $e a a_{i j} w$ & quantitative & - & WB \\
Exchange rate LCY per USD & Unit & $l c y \_u s d$ & quantitative &,+- & UNCTAD \\
\hline
\end{tabular}

Source: Own elaboration, 2020.

We also want to test one specific factor that may influence bilateral trade flows between the EU and BRICS countries. We assume a strong trade effect between Russia and countries that are currently the EU members, but which were members of the Council of Mutual Economic Assistance (CMEA) in the past. Simply said, the hypothesis is that the division of Europe into the West and East during the Cold War era can still drive the recent mutual trade among its former members to some extent. Therefore, the dummy variable cmea $_{i j t}$ takes the value 1 if both countries of the pair used to be the members of the CMEA before 1991, 0 otherwise.

The last group of variables contains time-variant trade policy variables; quantitative as well as dummy variables representing any tool of the trade policy that is supposed to be observed. Most of the studies use dummy variables representing multilateral or bilateral trade agreements among the trading partners. The commonly used variable is the World Trade Organization (WTO) (2020) membership $w t o_{i j t}$, which takes the value 1 , if both countries of the pair are members of the WTO in time $t, 0$ otherwise. A positive effect of the WTO was found in Rose (2005) or Eicher and Henn (2011). The mainstream approach to estimate the effect of the preferential trade agreement $f t a_{i j t}$ is using a dummy variable that takes the value 1 if the preferential trade policy affects bilateral imports (see Baier, Yotov 
and Zylkin, 2019), 0 otherwise. The advantage of this method is its easy implementation; however, if there is no reciprocal preferential trade agreement between countries, the identification for the policy measure may be biased (De Benedictis and Taglioni, 2011; Gill-Pareja, Llorca-Vivero and Martinez-Serrano, 2017).

There are very few papers on the gravity model that use tariff rate values (Wilson, Mann and Otsuki, 2003; or Lee and Park, 2007) due to the lack of data about bilateral tariffs applied in certain years (United Nations, 2012). Therefore, the last but very essential variable that will be observed is the weighted average effective applied tariff rate, which is imposed on country $j$ 's imports from country $i$ in year $t$ expressed by $e a r_{-} w a_{i j t}$.

No gravity equation should miss the effect of the exchange rate. We use the annual average of the local currency (LCY) per USD of each country as most international transactions are made in USD. According to the economic theory, the depreciation of the local currencies against USD has a negative effect on domestic imports.

It is important to note that all variables such as import, gross domestic product, distance, tariffs and exchange rates will enter the panel regression analysis in the logarithmic form, while the other variables as dummy variables.

\subsection{Specification of the Estimated Structural Gravity Model}

In this section, the theoretical form of the structural gravity equation of Anderson and van Wincoop (2003) is transformed into the stochastic multiplicative form with the error term $\varepsilon i j$ and with the dependent variable of bilateral imports $I M_{i j}$ and used in the models:

$$
I M_{i j}=\frac{Y_{i}^{\beta_{1}} Y_{j}^{\beta_{2}} i}{Y_{w}^{\beta_{3}}}\left(\frac{t_{i j}^{\beta_{4}}}{p_{j}^{\beta_{5}} p_{i}^{\beta_{6}}}\right)^{1-\sigma} \varepsilon_{i j}
$$

where $\beta_{1}, \ldots, \beta_{6}$ represents the unknown parameters of variables. Log-linearizing equation 1 , one can obtain the estimated gravity equation:

$$
\begin{aligned}
& \ln I M_{i j}=\beta_{0}+\beta_{1} \ln Y_{i}+\beta_{2} \ln Y_{j}-\beta_{3} \ln Y_{q}+ \\
& +(1-\sigma)\left[\beta_{4} \ln t_{i j}-\beta_{5} \ln P_{j}-\beta_{6} \ln P_{i}\right]+\ln \varepsilon_{i j}
\end{aligned}
$$

with parameters $\beta_{1}, \ldots, \beta_{6}$ as elasticities that need to be estimated and $\ln \varepsilon_{i j}$ that depends on the higher moments of $\varepsilon_{i j}$, including its variance. In this form, the gravity equations will be estimated by the OLS methods. However, as Shepherd (2013) emphasizes, the gravity models usually suffer from heteroskedastic error terms violating the OLS assumptions and causing biased and inconsistent estimates. This issue can be solved by a non-linear estimation method like the Pseudo 
Poisson Maximum Likelihood, which has more plausible properties (see Piermartini and Yotov, 2016). Therefore, all gravity equations are also estimated in the non-linear form:

$$
I M_{i j}=\exp \left(\begin{array}{l}
\beta_{0}+\beta_{1} \ln Y_{i}+\beta_{2} \ln Y_{j}-\beta_{3} \ln Y_{q}+ \\
+(1-\sigma)\left[\beta_{4} \ln t_{i j}-\beta_{5} \ln P_{j}-\beta_{6} \ln P_{i}\right]
\end{array}\right) * \ln \varepsilon_{i j}
$$

Estimated gravity equations contain all variables presented in Table 1. Using equation 4 , focus is put on the effect of trade policy measures on bilateral import. The final equation takes the form:

$$
\begin{aligned}
& \ln I M_{i j}=\alpha_{i}+\gamma_{j}+\delta_{t}+\beta_{1} \ln Y_{i t}+\beta_{2} \ln Y_{j t}-\beta_{3} \ln d i s t_{i j t}+\beta_{4} c m e a_{i j t}- \\
& -\beta_{5} w t o_{j t}-\beta_{6} f t a_{i j t}+\beta_{7} \ln e a r \_w a_{i j t}+\beta_{8} \ln l c y \_u s d_{t}+\varepsilon_{i j t}
\end{aligned}
$$

where $i$ always means the country of export, $j$ means the country of import and $t$ the given year. The dependent variable $I M_{i j t}$ thus represents the import of country $j$ from country $i$ in time $t$.

The parameter $\alpha_{i}$ controls for the country of export, $\gamma_{j}$ for the country of import and $\delta_{t}$ for the time effect. From the econometric point of view, the country-specific effects $\alpha, \gamma$ and $\delta$ can be treated as fixed parameters (a fixed effect model) or random variables (a random effect model). We use the country fixed effects in order to gain specific information on included countries. As Mátyás (1997) emphasizes, country specific parameters represent the effects that influence the behavior of the value of imports beyond those explained by the regressors included in the model. A relatively high value of target specific effects indicates the openness of the economy. The parameter $\alpha_{i}$ indicates the efficiency of the exporter to export relatively to other countries in the sample as well as relative to its given size. This can also be applied on parameter $\gamma_{j}$, which shows a relative efficiency of the country of import. The last parameter $\delta_{t}$ shows time-varying features to capture global trends such as global inflation, economic growth or economic shocks. Country-specific time-varying fixed effects approximate for the multilateral trade resistance terms that are unobservable because they do not correspond to any price indices observed by statistics (Baier, Kerr and Yotov, 2018), as well as for other observable and unobservable characteristics that vary over time across countries (Shepherd, 2013).

Finally, we follow the newest methodology of Baier, Kerr and Yotov (2018). The panel data structure offers several benefits for estimation such as using the country-specific and country-pair fixed effects, improving estimation efficiency and addressing the issue of endogeneity. Using time intervals helps us to address the time inconsistency of the trade policy or other changes in trade costs. Country-pair 
fixed effects account for the endogeneity of regional trade agreements and offer a simple solution to control for the effects of all time-invariant bilateral trade costs. Using the Poisson Pseudo-Maximum Likelihood (PPML) estimator offers an easy solution for solving heteroscedasticity and zero trade flows issues, which are very common in the gravity models. Moreover, it ensures that the gravity effects are identical to their corresponding structural terms and generates more robust estimates.

\section{Empirical Results}

\subsection{Panel Gravity Model Verification Tests}

Before the results discussion, it is necessary to provide specification tests to accomplish the basic assumptions of the OLS estimation that leads to unbiased results. First, the assumption of linearity in parameters was confirmed after the logarithmic transformation. However, we found that several parameters had a better fit in the non-linear form (especially distance and tariffs). It creates additional reason to employ the non-linear PPML estimator.

The heteroscedasticity test confirmed the presence of heteroscedasticity since the residual variance decreases as the value of import growth. Hence, the variance of residuals is not constant, although it is expected to be. ${ }^{13}$ Nevertheless, as heteroscedasticity is a very frequent problem in gravity models, these findings are not surprising. As Shepherd (2013) emphasizes, the gravity equation should always use the robust standard errors procedure, which is a simple and effective way to fix the violation of the homoscedasticity assumption. Moreover, one of the major positive features of the PPML estimator is that it can account for the bias caused by the logarithmic transformation of the gravity equation in the case of heteroscedasticity in the error term.

In the same manner, gravity models often use robust standard errors or any clustering technique correcting the correlation of the error terms within the groups, defined by the variable identifying each country-pair independently. Serial correlation tests proved the presence of autocorrelation which causes smaller standard errors and increases the coefficient of determination. ${ }^{14}$ Using clustering techniques causes that standard errors estimates are robust to disturbances being autocorrelated. For the above-mentioned reasons, we use country-pair clustered standard errors in our models.

\footnotetext{
${ }^{13}$ The presence of heteroscedasticity was tested using the White Test heteroscedasticity.

${ }^{14}$ The presence of autocorrelation was tested by the Wooldridge Test for autocorrelation in panel data.
} 


\subsection{Effect of Trade Policy Measures on Bilateral Imports between the EU Members and BRICS Countries}

This section provides the estimation of trade policy measures on bilateral imports between the EU and BRICS countries that will help to confirm or reject the research hypothesis. We will test whether liberalization significantly boosted trade among the observed countries and whether the protectionist barriers, represented by bilateral tariffs, still have a significant effect in the given period.

Gravity literature usually uses more model estimators that are compared with each other to confirm the direction and size of the effects of the determinants on trade. Therefore, this approach is followed, and all gravity models are estimated by the panel fixed effect and the random effect model and finally by the PPML estimator. The pooled OLS estimation is used only as a point of reference. The fixed and random effect estimators are the most common in gravity literature. However, we consider the PPML estimator as the most efficient due to the above-mentioned reasons. Therefore, we will mostly comment on its results.

Table 2 shows the results of the estimation of equation 4 describing the effect of trade policy measures on trade between the EU and BRICS countries. The dataset includes a total of 140 country-pairs holding 2,617 observations for the model of BRICS imports and 2,722 observations for the model of EU imports in the period $1995-2016$. The difference is caused by some missing import data in the sample. However, as we use time intervals in order to address the time inconsistency of the trade policy or other changes in trade costs, the number of observations drops to one third (we use a 3-year interval). According to the F-test, all models had a high value of Wald statistics indicating a strong joint significance of variables, which is completed by enough value of the goodness of fit. All models control for the multilateral trade resistance terms. Moreover, in the fixed effect model and PPML model, we use country-pair fixed effects to control for the model endogeneity.

Most of the GDP elasticities are close to unity, hence they follow the properties of the structural gravity model set by Anderson and van Wincoop (2003). As expected, both the exporter's and importer's GDP have a positive impact on bilateral imports. The results suggest that the EU Members have a higher effect on bilateral trade flows than the economic size of the BRICS countries. It is the most evident on the side of the EU imports. While the estimation of BRICS imports suggests a similar effect of the supply and demand size of the economy, the estimation of EU imports clearly shows that the purchasing power lies on the EU side.

The effect of distance is also in line with the theory of the gravity model as it keeps a high negative effect on bilateral imports. Table 2 shows that a $1 \%$ growth of distance between the EU and BRICS countries has a significantly negative effect 
in both directions; however, higher for the EU imports. We assume that this might be caused by higher costs when approaching the Common Market, higher nontariff barriers, or the fact that some EU countries do not have access to the sea. ${ }^{15}$

Table 2

Estimates of the Panel Gravity Model with Trade Policy Measures

\begin{tabular}{|c|c|c|c|c|c|c|c|c|}
\hline & \multicolumn{4}{|c|}{ BRICS imports from the EU } & \multicolumn{4}{|c|}{ EU imports from BRICS } \\
\hline & (1) & (2) & (3) & (4) & (1) & (2) & (3) & (4) \\
\hline & OLS & $\mathrm{FE}$ & $\mathrm{RE}$ & PPML & OLS & $\mathrm{FE}$ & RE & PPML \\
\hline GDP exporter & $1.33 * * *$ & $1.31 * * *$ & $1.31^{* * * *}$ & $0.78 * * *$ & $0.60 * *$ & $0.42 *$ & $0.45^{*}$ & $0.32 * * *$ \\
\hline GDP importer & $0.75^{\prime}$ & $0.83^{*}$ & 0.81 & $0.56^{* * * *}$ & $0.58 * *$ & $0.69^{* * *}$ & $0.67 * *$ & $1.30^{* * * *}$ \\
\hline Distance & $-1.61 * * *$ & & $-1.63 * * *$ & $-0.87 * * *$ & $-1.38^{* * * *}$ & & $-1.34 * * *$ & $-1.71 * * *$ \\
\hline CMEA & $1.08^{* * *}$ & & $1.07 * * *$ & 0.27 & $1.57 * * *$ & & $1.61 * * *$ & $1.75 * * *$ \\
\hline WTO & $0.26^{*}$ & $0.21 *$ & $0.23 *$ & 0.12 & 0.08 & 0.13 & 0.12 & -0.02 \\
\hline $\begin{array}{l}\text { FTA } \\
\text { IMPORTER'S }\end{array}$ & 0.34 & $0.46^{*}$ & $0.43^{*}$ & $0.94 * * *$ & 0.36 & -0.32 & -0.23 & -0.44 \\
\hline TARI & $-0.27 * *$ & $-0.33^{* *}$ & $-0.32 * *$ & -0.02 & -0.08 & $-0.09 * *$ & $-0.09 * *$ & -0.03 \\
\hline LCY/USD & $-0.70 *$ & $-0.65 *$ & $-0.66 *$ & $-0.31 * * *$ & -0.14 & -0.3 & -0.28 & $-0.24 * * *$ \\
\hline _cons & -4.92 & $-19.84 * * *$ & -5.4 & $-2.05 *$ & 3.55 & $-7.34 * * *$ & 3.65 & $5.30 * * *$ \\
\hline Observations & 857 & 857 & 857 & 857 & 841 & 841 & 841 & 841 \\
\hline $\begin{array}{l}\text { Clustered/Robust } \\
\text { Standard Errors }\end{array}$ & YES & YES & YES & YES & YES & YES & YES & YES \\
\hline Time intervals & YES & YES & YES & YES & YES & YES & YES & YES \\
\hline $\begin{array}{l}\text { Country-pair } \\
\text { fixed effects }\end{array}$ & $\mathrm{NO}$ & YES & NO & YES & $\mathrm{NO}$ & YES & NO & YES \\
\hline $\begin{array}{l}\text { Control } \\
\text { for exporter }\end{array}$ & YES & YES & YES & YES & YES & YES & YES & YES \\
\hline $\begin{array}{l}\text { Control } \\
\text { for importer }\end{array}$ & YES & YES & YES & YES & YES & YES & YES & YES \\
\hline $\begin{array}{l}\text { Control for year } \\
\text { Coefficient }\end{array}$ & YES & YES & YES & YES & YES & YES & YES & YES \\
\hline of det & 0.91 & 0.57 & 0.69 & & 0.93 & 0.64 & 0.64 & \\
\hline
\end{tabular}

Legend: $* \mathrm{p}<0.05 ; * * \mathrm{p}<0.01 ; * * * \mathrm{p}<0.001$.

Source: Own calculation.

The variable representing the former Council for Mutual Economic Assistance (CMEA) membership offers very interesting results. The random effect model suggests a significantly positive effect of the former CMEA membership on the bilateral imports on both sides (higher on the side of EU imports). However, the PPML estimator clearly shows that while the EU Members are highly dependent on Russian exports (mainly commodities), ${ }^{16}$ the former CMEA trade links from the EU to Russia no longer apply.

\footnotetext{
${ }^{15}$ The highest volumes of the EU finished products are exported from the biggest EU countries (Germany, France, Italy, or the United Kingdom), while smaller countries work as their suppliers of intermediate production. However, the EU imports are delivered, to a large extent, directly to the end customer.

${ }^{16}$ Many EU Members that used to be a part of the USSR are highly or fully dependent on the oil and gas exports from Russia.
} 
Against our expectations, the results of both PPML models show that the WTO membership is no longer efficient for trade flows as the results are insignificant at the 5\% level of significance. Indeed, although the WTO is still seen as a guarantee of trade liberalization, the unsuccessful Doha round that has already been taking place for twenty years, significant increase of bilateral and regional trade agreements, and recent renewal of trade barriers indicate that the WTO potential is greatly exhausted. Therefore, we confirm the results of Rose (2005).

The effect of the EU-South Africa FTA is very different for each trade flow. The PPML results suggest that South Africa highly benefits from this agreement on the import side as lower or no tariffs and other Agreement benefits increased the scope of the purchased goods (of course, beneficial for the EU exporters). However, the effect on the EU Members' imports is insignificant. It confirms the results of Eicher and Henn (2011) that some FTAs may support trade greatly but unevenly.

Our results show a significantly negative effect of tariffs on trade between the EU and BRICS countries when applying the fixed and random effect models. It confirms the hypothesis, and economic theory as well, that tariffs create a barrier to trade. Both models suggest that the negative effect of tariffs is higher on the BRICS imports from the EU. It reflects higher tariff rates that were presented in Chapter 3.

In the case of the EU import from BRICS, the effects of tariffs are approximately three times smaller. It is caused by a lower level of tariffs applied on the EU imports and the liberalization process in the observed period while the tariffs applied on goods from the EU by the BRICS countries are still high.

Finally, the effect of currency depreciation is in line with our expectations. Our PPML results indicate that the one percent LCY depreciation against the USD has a negative impact on both import flows.

\subsection{Meta-Analysis Comparison and Robustness Test}

In 2014, Head and Mayer published the results of the meta-analysis consisting of all papers published in top-5 journals during the period $2006-2012$ and other specially selected studies, covering 159 papers and more than 2,500 usable estimates.

In Table 3, we compare our results with the results of this meta-analysis for the variables in common. In general, our estimations are in line with the metaanalysis; however, they differ in size due to our case study. The economic size of the exporter and the importer is significantly positive. Head and Mayer (2014) found the average of the GDP's coefficient to be $0.58-0.74$ for the structural 
gravity models. Their results found a stronger effect on the supply side than on the demand side, while our sample suggests a stronger effect of the EU on both sides of the trade relationship. The effects of distance are comparable with our findings. Finally, our results of the FTA are different as we consider only the EU-South Africa FTA. Here, our estimation is higher for the BRICS imports, while having no effect in the opposite direction.

T a ble 3

Comparison of Results with the Head and Mayer (2014) Meta-Analysis

\begin{tabular}{|l|c|c|c|c|}
\hline & \multicolumn{2}{|c|}{ Head and Mayer (2014) } & \multicolumn{2}{c|}{ Our PPML results } \\
\hline & All Gravity & Structural Gravity & $\begin{array}{c}\text { BRICS imports } \\
\text { from the EU }\end{array}$ & $\begin{array}{c}\text { EU imports } \\
\text { from BRICS }\end{array}$ \\
\hline Estimates & mean & mean & RE & RE \\
Origin GDP & .98 & .74 & $0.78^{* * *}$ & $0.32^{* * *}$ \\
Destination GDP & .84 & .58 & $0.65^{* * *}$ & $1.30^{* * *}$ \\
Distance & -.93 & -1.1 & $-0.87^{* * *}$ & $-1.71^{* * *}$ \\
Contiguity & .53 & .66 & - & - \\
Common language & .54 & .39 & - & - \\
Colonial link & .92 & .75 & - & -0.44 \\
RTA/FTA & .59 & .36 & $-16 * * *$ & - \\
EU & .14 & .76 & - & - \\
CUSA/NAFTA & .43 & .86 & - & - \\
Common currency & .79 & 1.9 & - & - \\
Home & 1.96 & .159 & - \\
\hline
\end{tabular}

Notes: The number of estimates is 2508 , obtained from 159 papers. Structural gravity refers here to some use of the country fixed effects or ratio-type method.

Source: Head and Mayer (2014); own calculation.

We also examined whether the effects of the gravity variables in our models are sensitive to alternative econometric approaches. We employ the Poisson regression estimator (POISS), the Generalized Least Squares estimator (GLS) and the Maximum Likelihood estimator (MLE). We keep robust standard errors, time intervals of three years as well as control for multilateral resistance terms. Compared to the PPML estimation, all alternative models show very similar results (see Annex 1). It suggests that our model is stable across all estimation methods.

All estimations show that the core of the gravity model (economic size and distance) holds in the direction and size. Our findings have three important implications. First, it is evident that the dependence of some EU countries on the Russian imports of commodities is high represented by a highly positive parameter for the former CMEA membership. Second, most of the models suggest that the WTO membership no longer benefits bilateral trade flows among the observed set of countries, while the tariffs are not that high to form a significant barrier to trade. Third, the EU-South Africa FTA benefits the EU exporters more, but not the EU consumers. 


\section{Conclusion}

The paper dealt with the bilateral trade flows between the EU Members and BRICS countries that have increased their role in the global economy, and especially for the EU market. A higher interest of the European Commission suggested in the EU Trade and Investment Strategy attracted our attention in order to analyze their bilateral trade flows in the last two decades. Despite the longterm intention of multilateral negotiations to include developing countries in the global supply chains, the recent escalation of trade disputes put a toll on global trade and raised economic uncertainties among the economic agents. Therefore, the aim of this paper was to estimate whether the liberalization process over the last two decades benefited the mutual trade between the EU and BRICS Members, and whether protectionism, which is currently on the rise, still represents a significant toll on bilateral trade among them. Our model is based on the common practices of gravity modelling as well as the most recent findings and technical upgrades to gain unbiased estimates.

Our results showed that the multilateral trade liberalization process, represented by the WTO, no longer benefits trade among the observed countries, as our results proved to be insignificant. The long-standing stalemate in the WTO may be the biggest reason for such results.

Since 2001, too little was done from the Doha round. Apart from some traditionally boycotting countries, everything was complicated by the current US administration which threatens to withdraw from the WTO. As a result, all countries prefer to negotiate bilateral and regional trade agreements. We have also found that the observed FTA between the EU and South Africa create trade strongly, but unevenly.

Finally, we found mixed results about the effect of tariff barriers. The PPML estimations suggest that the level of tariffs no longer represents a significant barrier to trade. The panel fixed effect and random effect models suggest a higher negative effect of tariffs on the side of the BRICS countries compared to the three times smaller negative effect on the side of the EU. The reason is that the EU is strongly pushing to reduce trade barriers in its trade negotiations and keeps lower tariffs on exports from the BRICS countries. Indeed, we saw that in the case of the EU-South Africa FTA and recent EU-Mercosur negotiations. Nevertheless, while tariff barriers decreased over the last two decades, non-tariff barriers came to the fore.

Many countries thus just pretend liberalization efforts. Watching the development in the WTO, the steps of some countries prove this approach. India and China are great examples. For this reason, we want to focus on the issue of nontariff barriers in our future research. 


\section{References}

ANDERSON, J. E. - VAN WINCOOP, E. (2003): Gravity with Gravitas: A Solution to the Border Puzzle. American Economic Review, 93, No. 1, pp. 170 - 192.

BAIER, S. L. - BERGSTRAN, J. H. (2007): Do Free Trade Agreements Actually Increase Members' International Trade Flows using Matching Econometrics. Journal of International Economics, 77 , No. 1 , pp. $63-76$.

BAIER, S. L. - KERR, A. - YOTOV, Y. V. (2018): Gravity, Distance, and International Trade. Handbook of International Trade and Transportation, pp. $15-78$.

BAIER, S. L. - YOTOV, Y. V. - ZYLKIN, T. (2019): On the Widely Differing Effects of Free Trade Agreements: Lessons from Twenty Years of Trade Integration. Journal of International Economics, 116, pp. $206-226$.

BALDWIN, R. - TAGLIONI, D. (2006): Trade Effects of the Euro: A Comparison of Estimators. Journal of Economic Integration, 22, No. 4, pp. $780-818$.

BEHAR, A. - VENABLES, A. J. (2011): Transport Costs and International Trade. A Handbook of Transport Economics, In: DE PALMA, A., LINDSEY, R., VICKERMAN, F. and VICKERMAN, R. (ed.): A Handbook of Transport Economics. Edward Elgar Publishing, pp. 273 - 478. ISBN 978-1-84720-203-1.

BRUN, J. - CARRERE, C. - GUILLAMONT, P. - DE MELO, J. (2002): Has Distance Died? Evidence from a Panel Gravity Model. World Bank Economic Review, 19, No. 1, pp. 99 - 120.

DE BENEDICTIS, L. - TAGLIONI, D. (2011): The Trade Impact of European Union Preferential Policies: An Analysis Through Gravity Models. Berlin: Springer-Verlag Berlin Heidelb. ISBN 978-3-642-16564-1.

DISDIER, A. C. - HEAD, K. (2008): The Puzzling Persistence of the Distance Effect on Bilateral Trade. The Review of Economics and Statistics, 90, No. 1, pp. $37-48$.

EICHER, T. S. - HENN, CH. (2011): In Search of WTO Trade Effects: Preferential Trade Agreements Promote Trade Strongly, but Unevenly. Journal of International Economics. 83, No. 2, pp. $137-153$.

EUROPEAN COMMISSION (2011): Trade, Growth and World Affairs: Trade Policy as a Core Component of the EU's 2020 Strategy. Available at: <https://www.eesc.europa.eu/en/ourwork/opinions-information-reports/opinions/trade-growth-and-world-affairs-trade-policy-corecomponent-eus-2020-strategy>.

EUROPEAN Commission (2020a): EU-Mercosur Trade Agreement. Available at: $<$ https://ec.europa.eu/trade/policy/in-focus/eu-mercosur-association-agreement/>.

EUROPEAN COMMISSION (2020b): India and the EU. Available at: <https://ec.europa.eu/trade/policy/countries-and-regions/countries/india/2.

EUROPEAN COMMISSION (2020c): China. Available at: $<$ https://ec.europa.eu/trade/policy/countries-and-regions/countries/china/>.

EUROPEAN COMMISSION (2020d): EU Relations with South Africa. Available at: $<$ https://ec.europa.eu/trade/policy/countries-and-regions/regions/sadc/>.

FUKAO, K. - OKUBO, T. - STERN, R. M. (2003): An Econometric Analysis of Trade Diversion under NAFTA. The North American Journal of Economic and Finance. 14, No. 1, pp. 2 - 24.

FURCERI, D. - HANNAN, A. S. - OSTRY, J. D. - ROSE, A. K. (2019): Macroeconomic Consequences of Tariffs. [IMF Working Paper 19/9.] Washington, DC: IMF.

GARRED, J. (2016): The Persistence of Trade Policy in China after WTO Accession. Journal of International Economics, 81, No. 2, pp. 163 - 169.

GENC, M. - LAW, D. (2014): A Gravity Model of Barriers to Trade in New Zealand. [New Zealand Treasury Working Paper 14/05.] Wellington: New Zealand Treasury. Available at: <http://hdl.handle.net/10419/205660>. 
GILL-PAREJA, S. - LLORCA-VIVERO, R. - MARTINEZ-SERRANO, J. A. (2017): Reciprocal vs Nonreciprocal Trade Agreements: Which Have Been Best to Promote Exports? Empirical Economics, 52, No. 1, pp. 143 - 154.

HEAD, K. (2003): Gravity for Beginners. Saggio presentato alla Conferenza: Rethinking the Line: The Canada-US Border Conference. Vancouver, British Columbia, 22.

HEAD, K. - MAYER, T. (2014): Gravity Equations: Workhorse, Toolkit, and Cookbook. Handbook of International Economics, No. 4, pp. 131 - 195.

HINOJOSA-VALENCIA, L. - HINOJOSA, L. - DG-TRADE, EU (2008): Sustainable Impact Assessment of the EU-Mercosur Trade Agreement. The Automotive and the Bio-fuels Sectors (Socio-economic Assessment on Livelihoods and Gender). Manchester: University of Manchester, Impact Assessment Research Center.

LAMPE, M. (2008): Bilateral Trade Flows in Europe, 1857 - 1875: A New Dataset. In: FIELD, A. J., SUNDSTORM, W. A. and CLARK, G. (ed.): Research in Economic History, 26, No. 1, pp. 81 - 155.

LEE, H. - PARK, I. (2007): In Search of Optimized Regional Trade Agreements and Applications to East Asia. The World Economy, 30, No. 5, pp. 783 - 806.

LONDON SCHOOL OF ECONOMICS (2019): Sustainability Impact Assessment in Support of the Association Agreement Negotiations between the European Union and Mercosur. Draft Interim Report. Available at: <http://www.eumercosursia.com/uploads/4/0/7/2/40728425/final_ interim_report_publication_03oct2019.pdf $>$.

MARTÍNEZ-ZARZOSO, I. - SUÁREZ-BURGEUT, C. (2005): Transport Costs and Trade: Empirical Evidence for Latin American Imports from the European Union. Journal of International Trade and Economic Development, 14, No. 3, pp. 353 - 371.

MÁTYÁS, L. (1997): Proper Econometric Specification of the Gravity Model. The World Economy, 20, No. 3, pp. $363-368$.

MELITZ, J. (2007): North, South and Distance in the Gravity Model. European Economic Review, 51, No. 4, pp. $971-991$.

PIERMARTINI, R. - YOTOV, Y. V. (2016): Estimating Trade Policy Effects with Structural Gravity. [WTO Working Paper ERSD-2016-10.] Geneva: WTO.

ROSE, A. K. (2005): Which International Institutions Promote Trade? American Economic Review, 13, No. 4, pp. $682-698$.

ROUZET, D. - MIROUDOT, S. (2013): The Cumulative Impact of Trade Barriers along the Value Chain: An Empirical Assessment Using the OECD Inter-Country Input-Output Model. [Presented at the 16th Annual Conference on Global Economic Analysis, Shanghai, China.] In: Global Trade Analysis Project (GTAP). West Lafayette: Purdue University. Available at: <https://www.gtap.agecon.purdue.edu/resources/res_display.asp?RecordID=4184>.

SHEPHERD, B. (2013): The Gravity Model of International Trade: A User Guide. Issue $2^{\text {nd }}$ ed. New York: United Nations Publication. ISBN 978-974-680-346-5.

SUBRAMANIAN, A. - WEI, S. J. (2007): The WTO Promotes Trade Strongly, but Unevenly. Journal of International Economics. 72, No. 1, pp. $151-175$.

TINBERGEN, J. (1962): Shaping the World Economy: Suggestions for an International Economic Policy. New York: The Twentieth Century Fund.

UNCTAD (2020): UNCTADStat. Available at: <https://unctadstat.unctad.org/wds/ReportFolders/reportFolders.aspx?sCS_ChosenLang=en>.

UNITED NATIONS (2012): A Practical Guide to Trade Policy Analysis. New York: United Nations Publications. ISBN 978-92-1-112855-0.

WILSON, J. S. - MANN, C. L. - OTSUKI, T. (2003): Trade Facilitation and Economic Development: A New Approach to Quantifying the Impact. World Bank Economic Review, 17, No. 3 , pp. $367-389$.

WORLD TRADE ORGANIZATION (2020): Members and Observers. Available at: <https://www.wto.org/english/thewto_e/whatis_e/tif_e/org6_e.htm>.

WORLD BANK (2020): World Integrated Trade Solutions. Washington, DC: World Bank. Available at: 〈https://wits.worldbank.org/WITS/WITS/Restricted/Login.aspx>. 
Annex 1

Robustness of the Estimated Gravity Model

\begin{tabular}{|c|c|c|c|c|c|c|c|c|}
\hline & \multicolumn{4}{|c|}{ BRICS imports from the EU } & \multicolumn{4}{|c|}{ EU imports from BRICS } \\
\hline & (1) & (2) & (3) & (4) & (1) & (2) & (3) & (4) \\
\hline & PPML & POIS & GLS & MLE & PPML & POIS & GLS & MLE \\
\hline GDP exporter & $0.78 * * *$ & $0.71 * * *$ & $1.33 * * *$ & $1.31 * * *$ & $0.32 * * *$ & $0.56^{* *}$ & $0.60 * * *$ & $0.45 * * *$ \\
\hline GDP importer & $0.56 * * *$ & $0.61 * * *$ & $0.75 * * *$ & $0.80 * * *$ & $1.30 * * *$ & $0.60 * *$ & $0.58 * *$ & $0.67 * * *$ \\
\hline Distance & $-0.87 * * *$ & $-0.99 * *$ & $-1.61 * * *$ & $-1.63 * * *$ & $-1.71 * * *$ & $-1.38 * * *$ & $-1.38 * * *$ & $-1.34 * * *$ \\
\hline CMEA & 0.27 & $1.21 * * *$ & $1.08 * * *$ & $1.07 * * *$ & $1.75^{* * *}$ & $0.88 * *$ & $1.57 * * *$ & $1.61 * * *$ \\
\hline WTO & 0.12 & 0.08 & $0.26^{*}$ & $0.23 * *$ & -0.02 & $0.16^{*}$ & 0.08 & 0.12 \\
\hline FTA & $0.94 * * *$ & $0.84 * * *$ & 0.34 & $0.43 *$ & -0.44 & $0.89 * *$ & 0.36 & -0.21 \\
\hline IMPORTER'S & & & & & & & & \\
\hline TARIFFS & -0.02 & 0.03 & -0.27 & $-0.31 * * *$ & -0.03 & -0.08 & $-0.08 * *$ & $-0.09 * * *$ \\
\hline LCY/USD & $-0.31 * * *$ & -0.22 & -0.70 & $-0.66^{* *}$ & $-0.24 * * *$ & -0.11 & -0.14 & $-0.28 *$ \\
\hline _cons & $-2.05^{*}$ & 0.06 & 2.53 & 2.35 & $5.30 * * *$ & 3.81 & $3.55^{*}$ & 3.66 \\
\hline Observations & 857 & 857 & 857 & 857 & 841 & 841 & 841 & 841 \\
\hline $\begin{array}{l}\text { Clustered/ } \\
\text { Robust SE }\end{array}$ & YES & YES & YES & YES & YES & YES & YES & YES \\
\hline Time intervals & YES & YES & YES & YES & YES & YES & YES & YES \\
\hline $\begin{array}{l}\text { Control } \\
\text { for exporter }\end{array}$ & YES & YES & YES & YES & YES & YES & YES & YES \\
\hline $\begin{array}{l}\text { Control } \\
\text { for importer }\end{array}$ & YES & YES & YES & YES & YES & YES & YES & YES \\
\hline $\begin{array}{l}\text { Control } \\
\text { for year }\end{array}$ & YES & YES & YES & YES & YES & YES & YES & YES \\
\hline $\begin{array}{l}\text { Country-pair } \\
\text { fixed effects }\end{array}$ & YES & NO & $\mathrm{NO}$ & $\mathrm{NO}$ & YES & $\mathrm{NO}$ & $\mathrm{NO}$ & NO \\
\hline
\end{tabular}

Legend: $* \mathrm{p}<0.05 ; * * \mathrm{p}<0.01 ; * * * \mathrm{p}<0.001$.

Source: Own calculation. 